BIOMEDICAL AND BIOSOCIAL ANTHROPOLOGY
$\begin{gathered}\text { Official Journal of the International Academy } \\ \text { of Integrative Anthropology } \\ \text { journal homepage: http://bba-journal.com }\end{gathered}$

\title{
Prevalence of nutritional deficiency in patients with oral and oropharyngeal cancer
}

\section{Kushta A. 0.}

National Pirogov Memorial Medical University, Vinnytsya, Ukraine

\section{ARTICLE INFO \\ Received: 10 March 2021 \\ Accepted: 12 April 2021 \\ UDC: 616-06:616.31-006.04:616.3- \\ 008.13}

\section{CORRESPONDING AUTHOR}

e-mail: dr_anna9@ukr.net Kushta A. O.

\begin{abstract}
Tumors of the mouth and oropharynx are a significant group of malignant neoplasms characterized by a progressive increase in morbidity. Almost every patient has dysphagia and accounts for $90-95 \%$ of cases. Problems with swallowing in head and neck cancer may be associated primarily with the type and size of the tumor itself, which impairs the ability to eat. Therefore, the question of the presence of malnutrition in patients with oral and oropharyngeal cancer in the preoperative period and methods for detecting nutritional insufficiency remains open significant criteria for nutritional status violation. The aim of our study was to evaluate the frequency of nutritional insufficiency in patients with oncopathology of the oral cavity and oropharynx in the preoperative period and to identify the most significant criteria for nutritional status disorders. The results of nutritional status assessment of 46 patients with oncopathology of the oral cavity and oral pharynx in the preoperative period were analyzed. Somatometric (body mass index, shoulder circumference, skin-fat clot thickness) and laboratory (total blood protein, albumin, transfers, absolute lymphocyte count) methods were used. Mean values were reduced only for albumin and the absolute number of lymphocytes. Anthropometric indicators in the study group, with the exception of a moderate decrease in the size of the skin and fat folds in men, were within normal limits. Analyzing the data obtained, it was found that $85 \%$ (39 patients) of patients were malnourished. In 32 patients the disorders were mild, in 6 - moderate and one had severe malnutrition. When assessing the trophological status, it was found that one indicator was reduced in $35 \%$ (16/46), two - in $28 \%$ (13/46), three - in $31 \%$ (14/46), four - in $4 \%(2 / 46)$, five - in $2 \%$ (1/46). Malnutrition was detected by assessing the absolute number of lymphocytes in $71 \%$ and blood albumin in $63 \%$, the thickness of the skin and fat clot in $50 \%$. BMI assessment revealed grade I malnutrition in 7 patients, while malnutrition was detected in $85 \%$. Thus, comprehensive study revealed in the preoperative period in patients with oncopathology of the oral and oropharynx a high incidence of malnutrition (85\%). The main contribution to the change of trophological status is a decrease in the cellular component of immunity and albumin.

Keywords: nutritional status, nutritional deficiency, cancer, oral cavity, oropharynx.
\end{abstract}

\section{Introduction}

Tumors of the head and neck are a significant group of malignant neoplasms characterized by a progressive increase in morbidity. According to the consolidated data of the Global Burden of Disease Cancer Collaboration, more than 600 thousand new cases of head and neck cancer were registered in the world in 2018, while the death rate from oral and pharyngeal lesions alone exceeded 300 thousand people (which mainly observed during the first year of the disease) [3].

Despite the fact that these are tumors of visual localization, more than $70 \%$ of patients with newly diagnosed squamous cell carcinoma of the head and neck are diagnosed with common forms of the disease, characterized by significant tumor size with spread to adjacent structures, and $43 \%$ have regional and $10 \%$ remote metastases [6, 13].

One of the most important problems in the nutrition of patients with tumors of the oral cavity and oropharynx is dysphagia, which is present in almost every patient and accounts for $90-95 \%$ of cases, both in the preoperative and postoperative period. From 40 to $67 \%$ of patients with dysphagia have the so-called "silent aspiration", which 
complicates its timely diagnosis. Disorders of swallowing lead to malnutrition, exhaustion, metabolic and waterelectrolyte imbalance, dehydration, delayed wound healing, suture divergence and, as a consequence, to bedsores, constipation, urological infection, accompanied by the development of severe depression [5, 16].

Problems with swallowing in head and neck cancer may be associated primarily with the type and size of the tumor itself, which impairs the ability to eat. Disorders of pushing the food lump develop due to dysfunction of the affected muscles or damage to peripheral nerves. Anatomical disorders are primarily associated with the consequences of surgery, in which the block with the removed tumor includes functionally important muscles, and in some cases, fragments of the jaws [14]. In addition, there are early and late disorders of normal swallowing after radiation and chemotherapy for malignant tumors of the oral cavity, oropharynx and larynx.

It is in such patients that there is nutritional insufficiency in the preoperative period. In addition, nutritional deficiency is exacerbated in the postoperative period due to the dissociation between growing on the background of stress protein and energy needs and the ability to meet them. Thus, according to the literature, one of the main reasons for the development of nutritional insufficiency are postoperative defects of the oral cavity and oral pharynx [2, 9]. Also in the postoperative period, patients are particularly vulnerable to the development of complications associated with malnutrition, especially infectious. According to the European Community of Parenteral and Enteral Nutrition (ESPEN), the incidence of malnutrition in cancer patients ranges from $46 \%$ to $88 \%$ and in its maximum manifestation (anorexia-cachexia syndrome) is the direct cause of death $[8,11]$.

Therefore, the question of the presence of malnutrition in cancer patients of the oral and oropharynx in the preoperative period and methods of detecting nutritional deficiency remains open.

The aim of our study was to evaluate the frequency of nutritional insufficiency in patients with oncopathology of the oral cavity and oropharynx in the preoperative period and to identify the most significant criteria for nutritional status disorders.

\section{Materials and methods}

The study was conducted in 46 patients aged 38-55 years (30 men, 16 women) who were treated in the Department of Head and Neck Tumors "Podillia Regional Oncology Center" with malignant tumors of the lips, tongue, mouth and oropharynx I-III stage. All patients had problems with chewing and swallowing, which is typical of patients with tumor processes of the next localization (cancer of the tongue - 22, the mucous membrane of the bottom of the mouth - 16 and the anterior palatine arch - 8). Patients with stage IV were not included in the study because they required only palliative treatment.
Body mass index (BMI), shoulder circumference (SC) and triceps skinfold thickness (TSFT), total serum protein, albumin, transferrin was evaluated. Measurements of shoulder circumference were performed with an ordinary centimeter tape at the level of the middle third of the nonworking arm. There, with the help of a caliper, the thickness of the skinfold was measured. Assessment of BMI was performed according to WHO recommendations: $<18.5 \mathrm{~kg} /$ $\mathrm{m}^{2}$ (malnutrition), $18.5-24.9 \mathrm{~kg} / \mathrm{m}^{2}$ (normal), $25.0-29.9 \mathrm{~kg} /$ $\mathrm{m}$ ? (overweight), $>30.0 \mathrm{~kg} / \mathrm{m}^{2}$ (obesity). Note that the range of values from 18.5 to $19.9 \mathrm{~kg} / \mathrm{m}^{2}$ corresponds to the deficit of body weight. Extended assessment of the trophological status of the patient was performed according to the generally accepted method [8, 11], shown in table 2 .

Nutritional status studies were performed at the initial treatment of the patient, at the time of diagnosis and before surgery.

Data processing was performed using the program "Statistica 6.0" and Exel. During the statistical analysis, the obtained data with normal distribution are presented as the mean and standard deviation. Statistically significant were the results in which the value of the criterion corresponded to the condition $p<0.05$.

\section{Results}

The average values of anthropometric indicators in the study group, except for a moderate decrease in the size of the skin and fat folds in men, were within normal limits.

There was a decrease in the absolute number of lymphocytes, less than 1.5 thousand in $1 \mu \mathrm{l}(\mathrm{p}<0.05)$, in $71 \%(33 / 46)$. Indicators characterizing the visceral protein pool (total protein, transferrin) were also within normal values, except for albumin, which was slightly reduced by $63 \%$ (Table 1).

Analyzing the data obtained, it was found that $85 \%$ (39 patients) of patients were malnourished. In 32 patients the disorders were mild, in 6 - moderate and one had severe malnutrition.

When assessing the trophological status, it was found that one indicator was reduced in $35 \%(16 / 46)$, two - in

Table 1. Characteristics of patients $(M \pm \sigma)$.

\begin{tabular}{|c|c|c|c|}
\hline Indicat & & Average values & Normal values \\
\hline \multicolumn{4}{|c|}{ Anthropometric indicators } \\
\hline \multicolumn{2}{|c|}{ BMl assessment $\left(\mathrm{kg} / \mathrm{m}^{2}\right)$} & $25.74 \pm 4.23$ & $20.0-25.0$ \\
\hline $\begin{array}{l}\text { Shoulder } \\
\text { circumference }(\mathrm{cm})\end{array}$ & $\begin{array}{c}\text { men } \\
\text { women }\end{array}$ & $\begin{array}{l}29.82 \pm 2.74 \\
29.74 \pm 5.02\end{array}$ & $\begin{array}{l}\geq 26.0 \\
\geq 25.0\end{array}$ \\
\hline TSFT (mm) & $\begin{array}{c}\text { men } \\
\text { women }\end{array}$ & $\begin{array}{c}8.83 \pm 3.52^{*} \\
12.14 \pm 4.24^{*}\end{array}$ & $\begin{array}{l}\geq 9.5 \\
\geq 3.0\end{array}$ \\
\hline \multicolumn{4}{|c|}{ Biochemical markers } \\
\hline \multicolumn{2}{|l|}{ Total protein $(\mathrm{g} / \mathrm{l})$} & $72.93 \pm 7.34$ & $\geq 65.0$ \\
\hline \multicolumn{2}{|l|}{ Albumin $(g /)$} & $31.35 \pm 3.23^{*}$ & $\geq 35.0$ \\
\hline \multicolumn{2}{|l|}{ Transferrin (g/) } & $2.64 \pm 0.74$ & $\geq 2.0$ \\
\hline \multicolumn{2}{|c|}{ Lymphocytes (thousands in $1 \mu \mathrm{l}$ ) } & $1.52 \pm 0.54^{*}$ & $>1.8$ \\
\hline
\end{tabular}


Table 2. Assessment of trophological status of patients.

\begin{tabular}{|c|c|c|c|c|c|}
\hline \multirow{2}{*}{\multicolumn{2}{|c|}{ Indicator }} & \multirow{2}{*}{$\begin{array}{l}\text { Normal } \\
\text { values }\end{array}$} & \multicolumn{3}{|c|}{ Malnutrition } \\
\hline & & & mild & moderate & severe \\
\hline \multicolumn{2}{|c|}{ BMI assessment $\left(\mathrm{kg} / \mathrm{m}^{2}\right)$} & $26.0-18.6$ & $18.5-17.0$ & $16.9-15.0$ & $<15.0$ \\
\hline $\begin{array}{l}\text { Shoulder } \\
\text { circumference } \\
(\mathrm{cm})\end{array}$ & $\begin{array}{c}\text { men } \\
\text { women }\end{array}$ & $\begin{array}{l}29.0-26.0 \\
28.0-25.0\end{array}$ & $\begin{array}{l}25.9-23.0 \\
24.9-22.5\end{array}$ & $\begin{array}{l}22.9-20.0 \\
22.4-19.5\end{array}$ & $\begin{array}{l}<20.0 \\
<19.5\end{array}$ \\
\hline TSFT (mm) & $\begin{array}{c}\text { men } \\
\text { women }\end{array}$ & $\begin{array}{c}10.5-9.5 \\
14.5-13.0\end{array}$ & $\begin{array}{c}9.4-8.4 \\
12.9-11.6\end{array}$ & $\begin{array}{c}8.3-7.4 \\
11.5-10.1\end{array}$ & $\begin{array}{l}<7.4 \\
<10.1\end{array}$ \\
\hline \multicolumn{2}{|l|}{ Total protein $(\mathrm{g} / \mathrm{l})$} & $>65.0$ & $55.0-65.0$ & $45.0-55.0$ & $<45.0$ \\
\hline \multicolumn{2}{|l|}{ Albumin $(g / l)$} & $>35.0$ & $35.0-30.0$ & $29.0-25.0$ & $<25.0$ \\
\hline \multicolumn{2}{|l|}{ Transferrin (g/l) } & $>2.0$ & $2.0-1.8$ & $1.7-1.6$ & $<1.6$ \\
\hline \multicolumn{2}{|c|}{$\begin{array}{l}\text { Lymphocytes } \\
\text { (thousands in } 1 \mu \mathrm{l} \text { ) }\end{array}$} & $>1.8$ & $1.8-1.5$ & $1.4-0.9$ & $<0.9$ \\
\hline \multicolumn{2}{|c|}{ Number of patients } & 7 & 32 & 6 & 1 \\
\hline
\end{tabular}

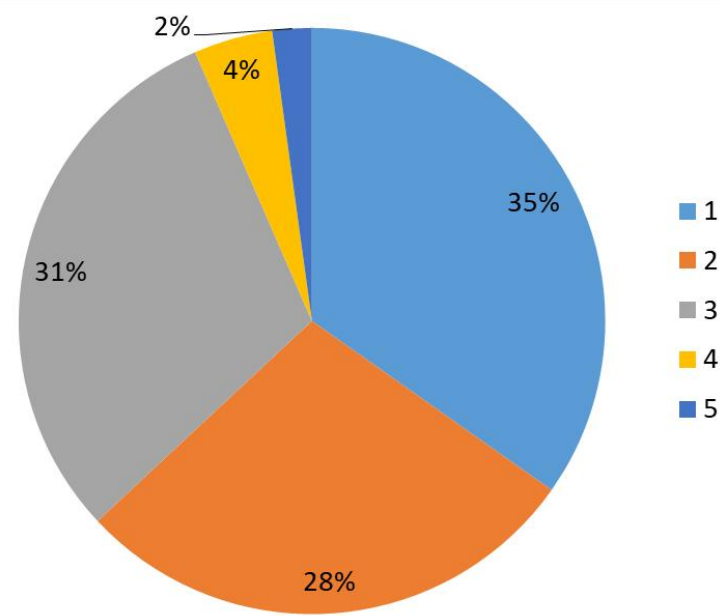

Fig. 1. Status of trophological status. 1 - reduced one indicator; 2 - reduced two indicators; 3 - reduced three indicators; 4 - reduced four indicators; 5 - reduced five indicators.

Table 3. Frequency of nutritional deficiency based on extended assessment of trophological status in patients depending on BMI.

\begin{tabular}{|l|c|c|}
\hline $\begin{array}{c}\text { Assessment of } \\
\text { trophological status }\end{array}$ & $\begin{array}{c}\text { Without nutritional } \\
\text { deficiency }\end{array}$ & $\begin{array}{c}\text { Nutritional } \\
\text { insufficiency }\end{array}$ \\
\hline Malnutrition & - & 7 \\
\hline Normal body weight & 3 & 12 \\
\hline Excess body weight & 5 & 13 \\
\hline Obesity & 2 & 4 \\
\hline Total & 10 & 36 \\
\hline
\end{tabular}

$28 \%(13 / 46)$, three - in $31 \%(14 / 46)$, four - in $4 \%(2 / 46), 5$ - in $2 \%(1 / 46)$ (Fig. 1).

Assessment by body mass index allowed to establish grade I malnutrition, ie malnutrition, only in 2 patients, BMI was 17.9 and $18.4 \mathrm{~kg} / \mathrm{m}^{2}$, respectively. In overweight patients, malnutrition, according to our data, was detected in $78 \%$ of cases $(13 / 18)$, with obesity - in $80 \%(4 / 6)$, with normal BMI - in $85 \%(12 / 15)$ (Table 3).

Each of the somatometric and clinical and laboratory indicators to varying degrees is able to detect nutritional
Table 4. Assessment of the patient's trophological status based on each indicator.

\begin{tabular}{|l|c|c|}
\hline \multicolumn{1}{|c|}{ Indicators } & $\begin{array}{c}\text { Number of patients } \\
\text { with norm }\end{array}$ & $\begin{array}{c}\text { Number of patients with } \\
\text { a decrease }\end{array}$ \\
\hline BMI & 39 & 7 \\
\hline SC & 36 & 10 \\
\hline TSFT & 22 & 24 \\
\hline Total protein & 39 & 7 \\
\hline Albumin & 23 & 23 \\
\hline Transferrin & 37 & 9 \\
\hline Lymphocytes & 13 & 33 \\
\hline
\end{tabular}

deficiencies. In our study, the most obvious malnutrition showed an absolute lymphocyte count of $71 \%$ (33/46), albumin and a TSFT $50 \%(23 / 46)$. Indicators which were less sensitive: total protein $15 \%(7 / 46)$, transferrin $19 \%$ (9/46) and shoulder circumference $22 \%(10 / 46)$ (Table 4).

\section{Discussion}

Cancer and various methods of its treatment can significantly affect metabolism and lead to exhaustion and weakening of the body. Even in the early stages, a malignant tumor is a disease that affects the body as a whole. Both the cells of the tumor itself and the cells of the body in response to changes caused by the tumor can secrete various substances that disrupt metabolic processes [12]. Such violations lead to the weakening of the patient, reduce his ability to fight the disease.

Many different mechanisms for the development of cancer depletion have been described [4]. In general, the body is restructuring for maximum nutrition of the tumor from all available sources: there is a breakdown of adipose and muscle tissue, inadequate use of energy that comes from food [8]. In this case, depletion also progresses with the presence of tumors in the upper digestive tract. Violation of the balance between the intake of nutrients in the body and its needs leads to the development of nutritional deficiency, which is characterized by syndromes of deficiency of energy, protein, vitamins, trace elements and electrolytes [1]. The pathogenesis of nutritional deficiency in oncology is multifactorial and includes cancer anorexia-cachexia syndrome, gastrointestinal tumor obstruction, recurrent bleeding, psychological distress, exposure to symptoms such as pain, chewing disorders, swallowing, nausea, vomiting, constipation, diarrhea. Neoadjuvant treatment can contribute - chemotherapy and radiation therapy, which are also very aggressive $[7,15]$. In addition, the technical features of surgical interventions performed in these diseases, create restrictions on adequate nutrition for 7 days or more, which is already a factor in nutritional risk, even in the absence of severe insufficiency before surgery [18]. The generally accepted methods of research of nutritional insufficiency include clinical, somatometric, laboratory and functional research methods.

Identification of patients with possible eating disorders 
usually begins with a screening procedure. There are a number of methods: NRS 2002 (Nutritional Risk Screening), recommended by the European Society of Clinical Nutrition and Metabolism ESPEN, or MNA questionnaire (Mini Nutritional Assessment) [10, 11, 17], MUST screening (Malnutrition Universal Screening Tool), Subjective Global Assessment (SGA) [8]. When detecting nutritional risk, a detailed analysis is performed using various somatometric parameters and formulas: BMI, SC, TSFT $[11,13]$. Measurement of SC and TSFT characterizes the state of muscle mass (somatic pool of protein) and fat depot. A decrease in $S C$ by only $1 \mathrm{~cm}$, as a rule, indicates a decrease in BM by $1.5 \mathrm{~kg}$, and the probability of mortality increases by $0.89, p=0.0087$. The study of laboratory parameters characterizing the trophological status has prognostic value. Thus, a decrease in albumin less than $25 \mathrm{~g} / \mathrm{l}$ increases the risk of postoperative complications by 4 , and mortality by 6 times [8]. Thus, anthropometric data allow to estimate the somatic pool of protein (skeletal muscle), and the level of total protein, albumin and transferrin - visceral pool.

One of the immunological evaluation criteria is the absolute number of lymphocytes, which reflects the severity of protein-energy deficiency by the degree of suppression of the immune system.

It is known that patients who are overweight or obese often mask significant weight loss, creating the illusion of a stable condition. Comprehensive assessment of

\section{References}

[1] Arends, J., Bachmann, P., Baracos, V., Barthelemy, N., Bertz, H., Bozzetti, F., ... \& Preiser, J. C. (2017). ESPEN guidelines on nutrition in cancer patients. Clinical nutrition, 36(1), 11-48. doi: 10.1016/j.clnu.2016.07.015

[2] Boyko, A. V., Gevorkov, A. R., Volkova, E. E., \& Shashkov, S. V. (2017). Нутритивная поддержка как обязательный компонент терапии сопровождения при лучевом и химиолучевом лечении больных с опухолями головы и шеи [Nutritional support as an obligatory component of accompanying therapy in radiation and chemoradiation treatment of patients with head and neck tumors]. Опухоли головы и шеи - Head and neck tumors, 7(1), 50-60. doi: 10.17650/2222-1468-2017-7-1-50-60

[3] Bray, F., Ferlay, J., Soerjomataram, I., Siegel, R. L., Torre, L. A., \& Jemal, A. (2018). Global cancer statistics 2018: GLOBOCAN estimates of incidence and mortality worldwide for 36 cancers in 185 countries. CA Cancer J Clin, 68(6), 394-424. doi: 10.3322/caac.21492

[4] Cuhls, H., Marinova, M., Kaasa, S., Stieber, C., Conrad, R., Radbruch, L., \& Mucke, M. (2017). Asystematic review on the role of vitamins, minerals, proteins, and other supplements for the treatment of cachexia in cancer: a European Palliative Care Research Centre cachexia project. Journal of cachexia, sarcopenia and muscle, 8(1), 25-39. doi: 10.1002/jcsm.12127

[5] Druml, C., Ballmer, P. E., Druml, W., Oehmichen, F., Shenkin, A., Singer, P., ... \& Bischoff, S. C. (2016). ESPEN guideline on ethical aspects of artificial nutrition and hydration. Clinical Nutrition, 35(3), 545-556. doi: 10.1016/j.clnu.2016.02.006

[6] Ferlay, J., Ervik, M., Lam, F., Colombet, M., Mery, L., Pineros, M., ... \& Bray, F. (2018). Global cancer observatory: cancer today. trophological status allows to identify "hidden" violations.

In our study, the most sensitive and comparable with the final result of a comprehensive assessment of trophological status were the indicators of the absolute number of lymphocytes and albumin.

When assessing the trophological status for each somatometric and clinical and laboratory indicators separately, only the indicator of the absolute number of lymphocytes, albumin and the thickness of the skin-fat convolution allowed to sufficiently detect malnutrition in the study group. Therefore, nutritional deficiency is one of the main components of cancer.

\section{Conclusions}

1. A comprehensive study revealed in the preoperative period in patients with oncopathology of the oral and oropharynx a high incidence of malnutrition (85\%).

2. The main contribution to the change of trophological status is a decrease in the cellular component of immunity and albumin.

3. The revealed moderate disturbances of the trophological status deserve close attention of the clinician as can be the reason of perioperative complications in this group of patients.

4. The method used to assess the trophological status is simple and accessible to the doctor, does not take much time, but, unfortunately, is not routine in clinical practice.

Lyon, France: international agency for research on cancer, 1-6. Retrieved from https://gco.iarc.fr/today.

[7] Khoroshilov, I. E. (2018). Клиническое питание и нутриционная поддержка [Clinical nutrition and nutritional support]. СПб.:ЭЛБИ-СПб. - SPb.: ELBI-SPb.

[8] Klochkova, I. S., Astafyeva, L. I., Kadashev, B. A., Sidneva, Y. G. \& Kalinin, P. L. (2020). Патогенетические аспекты синдрома кахексии [Pathogenetic aspects of cachexia]. Ожирение и метаболизм - Obesity and metabolism, 17(1), 33-40. doi: 10.14341/omet10173

[9] Kravtzov, S. A., Kirillov, N. V. \& Korshunova, T. V. (2016). Алгоритм проведения нутритивной поддержки у больных со злокачественными новообразованиями орофарингеальной зоны [Algorithm of nutritional support in patients with malignant neoplasms of the oropharyngeal zone]. Опухоли головы и шеи - Head and neck tumors, 6(2), 26-34. doi: 10.17650/2222-1468-2016-6-2-26-34

[10] Leyderman, I. N., Gritsan, A. I., Zabolotskikh, I. B., Lomidze, S. V., Mazurok, V. A., Nekhaev, I. V., ... \& Yaroshetskiy, A. I. (2018). Perioperative nutritional support. Russian Federation of anesthesiologists and reanimatologists guidelines. Alexander Saltanov Intensive Care Herald, (3), 5-21. doi: 10.21320/1818-474X-2018-3-5-21

[11] Luft, V. M., Bagnenko, C. F., Shcherbuk Yu. A. (Ed.) (2010). Руководство по клиническому питанию [Guidelines for clinical nutrition]. СПб.: АРТ-ЭКСПРЕСС, 2010 - SPb.: ARTEXPRESS, 2010.

[12] Martin, L., Senesse, P., Gioulbasanis, I., Antoun, S., Bozzetti, F., Deans, C., ... \& Baracos, V. E. (2015). Diagnostic criteria for the classification of cancer-associated weight loss. 
Journal of Clinical Oncology, 33(1), 90-99. doi: 10.1200/ JCO.2014.56.1894

[13] National Cancer Institute (2020). The Surveillance, Epidemiology, and End Results Program. 2020. Rerived from https:// seer.cancer.gov

[14] Paches, A. І. (2013). Опухоли головы и шеи: клиническое руководство для врачей [Head and Neck Tumors: A Clinical Guide for Physicians]. М.: Практическая медицина, 2013 M. Practical Medicine, 2013.

[15] Schindler, A., Denaro, N., Russi, E. G., Pizzorni, N., Bossi, P., Merlotti, A., ... \& Murphy, B. (2015). Dysphagia in head and neck cancer patients treated with radiotherapy and systemic therapies: literature review and consensus. Critical reviews in oncology/hematology, 96(2), 372-384. doi: 10.1016/ j.critrevonc.2015.06.005
[16] Tirelli, G., Gatto, A., Boscolo, N. F, Bussani, R., Piccinato A, Marcuzzo, A. V. \& Tofanelli, M. (2018). Prognosis of oral cancer: a comparison of the staging systems given in the 7th and 8th editions of the American Joint Committee on cancer staging manual. Br J Oral Maxillofacial Surgery. 56(1), 8-13. doi: 10.1016/j.bjoms.2017.11.009

[17] Weimann, A., Braga, M., Carli, F., Higashiguchi T., Hubner M., Klek S., ... \& Singer, P. (2017). ESPEN guideline: Clinical nutrition in surgery. Clinical nutrition, 36(3), 623-650. doi: 10.1016/ j.clnu.2017.02.013

[18] Zhang, B., Najarali, Z., Ruo, L., Alhusaini, A., Solis, N., Valencia, M., ... \& Serrano, P. E. (2019). Effect of perioperative nutritional supplementation on postoperative complications-systematic review and meta-analysis. Journal of Gastrointestinal Surgery, 23(8), 1682-1693. doi: 10.1007/s11605-019-04173-5 